Volume 7 Issue 2, June 2020

Nationally Accredited Journal,

Decree No. B/4130/E5/E5.2.1/2019

\title{
The function of the Notary / PPAT In filing process Acquisition of Land Rights To Interests Investment in Regional Autonomy Era Based on Act No. 25 of 2007 concerning Foreign Investment
}

\begin{abstract}
Wahyuni $^{1}$ and Umar Ma'ruf ${ }^{2}$
Abstract. The purpose of this study are to: 1) To be able to know and analyze about the function of Notary / PPAT in Appeals Process Acquisition of Land Rights Under the Foreign Investment Regulations. 2.) To be able to know and analyze the Protection of Investor Interests Investing in the Era of Regional Autonomy Under the Foreign Investment Law. The method shows the procedure and process of a study undertaken to achieve an objective results. Method of normative juridical approach specifications in this research is descriptive analysis, the data collection method, literature (study document), with critical analysis and finding the problems and legal issues that will be examined and gather all the information related to the problems studied.

The results of this study concluded Function Notary / PPAT in the filing process of acquiring land rights based on foreign investment regulations number 25 in 2007 . The function of Notaries easier for the public to take legal actions both Indonesian citizens or citizens of foreign countries who participate in investing in Indonesia, The Indonesian government also needs to prepare for national law and the law of international relations to establish it. Government to maintain legal certainty for foreign investors without discrimination by being able to compete with domestic investors. Protection of the interests of investors in investing in regional autonomy based on legislation.

Keywords: Function of Notaries; Investments; Autonomy; Foreign Investment.
\end{abstract}

\section{Introduction}

The legal basis for provision of rights to land in the regulations governing the land contained in Article 4 Paragraph (1) BAL. The right to land is a right that gave the that has the right to use or benefit from land. ${ }^{3}$ The process of acquiring land rights in Indonesia, a legal act or event which resulted in obtaining rights to land and or buildings by private persons or entities. ${ }^{4}$ The right to land can only be owned by Indonesian citizens, so that foreign citizens can not have rights to the land, but only to obtain better rights management rights of exploitation in Indonesia. So that in conducting its business activities severely restricted foreign nationals, to be able to have rights to the land. Foreign investors in the market economy in Indonesia who want to invest in his own efforts, be restricted by laws and legislation in business activities in Indonesia.

Business competition is also a conflict in the investment activities of investors both domestic and foreign investor to be enforced equally and fairly. This raises competition law foreign investment No. 25 of 2007, which regulates about licensing and protection

\footnotetext{
${ }^{1}$ Student Master of Notary Program, Sultan Agung Islamic University, Semarang, email: wahyusi.sh05@gmail.com

${ }^{2}$ Lecturer, Faculty of Law, Sultan Agung Islamic University, Semarang

${ }^{3}$ Sudikno Mertokusumo, 2009, Perundang-undangan Agraria Indonesia, Yogyakarta: Liberty, p. 38

${ }^{4}$ Ibid
} 
for foreign investors coming in Indonesia. In terms of business licensing foreign capital should be no involvement of a notary, to exercise its authority, to create an authentic deed and the involvement in the statutes of a company, it is the duty and obligation of notaries who are legally recognized by the laws of Indonesia.

Notary function in the process of land rights as a means to be able to realize progress in the field of the Indonesian economy, especially by making assets or capital of foreign investors to participate in the establishment of an enterprise or invest in Indonesia. This study aims to determine and analyze the function of Notary / PPAT In filing process Acquisition of Land Rights Under the Foreign Investment Regulation; as well as the Investor Protection In the interest Investing in the Era of Regional Autonomy Under Regulation Legislation?

\section{Research And Discussion}

\subsection{Function Notary / PPAT In filing process Acquisition of Land Rights Under the Foreign Investment Regulations}

The function which is also the authority of the notary as a public official is to make authentic act on all deeds, agreements, and provisions required by legislation and / or desired by the stakeholders to be stated in an authentic deed, guaranteeing the creation date of the deed, save deed, give, copy, and official copies, all of it throughout the making of the deed it not also be assigned or excluded to other officials or any other person specified by law. Acting Notary Public has a role and a function to be able to carry out his profession. Notary profession to help people both in the land deed official positions (PPAT) obtained and given a position based on legislation or rule of law.

Notary functions relating to land in the land rights for foreign investors to invest in Indonesia, facilitate the investors in setting up or investing in Indonesia. Investment is expected that investors in Indonesia, it can also facilitate business activities and obtain legal protection in Indonesia. The rapid development of investment made developing countries should also be able to compete to bring foreign investors, especially with the new law on foreign investment. Act of investors stipulated in No. 25 of 2007 on Foreign Investment.

The capital investment for foreign investors in Indonesia under the rules of the main points of the agrarian and the statute books of civil law, for it to be able to obtain a land title or use rights, rights of exploitation in Indonesia investors also have to understand that. ${ }^{5}$ So that the function of the notary in running post shall provide information and explain anything what can be done to foreign investors to invest especially in terms of the establishment of a company's business activities.

Giving their concept of land rights can only be granted to Indonesian citizens, not foreign. These principles are in article 4 of the BAL, which foreigners or BHA (foreign legal entity) can only have the right to use, as it set out in Article 41-43 and BHA BAL to a foreign national residing and domiciled in Indonesia may be limited right to use and Business Rights.

Based on Government Regulation No. 41 of 1996 Article 5, the period of granting right to use only 50 (fifty) years which includes granting and renewal. This provision is in line with Government Regulation No. 40 of 1996 Article 45, the period granted right to use a maximum of 25 (twenty five) years and can be extended a maximum of 25 (twenty five) years, while its renewal has not been set. If accumulated, The right is

\footnotetext{
${ }^{5}$ ibid
} 
Volume 7 Issue 2, June 2020

Nationally Accredited Journal,

Decree No. B/4130/E5/E5.2.1/2019

given also for 50 (fifty) years. Both government regulation already contained in common norms and in accordance with the intent and signaling BAL.

Indonesian Government Regulation No. 103 of 2015 which is a replacement of Government Regulation No. 41 of 1996 states, foreigners residing in Indonesia can have a single house on the ground right or a single house on the ground right to use the above property rights, with term 30 (thirty) years, extended for 20 (twenty) years and can be renewed for a maximum period of 30 (thirty) years. According to the regulation, the right to use is given for 80 (eighty) years (including renewal for 30 (thirty) years).

In Article 22 Paragraph (1) that are on the concession for 95 (ninety five) years, HGB for 80 (eighty) years and Right of Use for 70 (seventy) years to investors both foreign and domestic, by the way can granted and extended in advance as well. ${ }^{6}$ The provision of Article 22 Paragraph (1) of Capital Market Law is considered contrary to the constitution (RI State Constitution of 1945) due to the spirit of giving maximum profits for investors, have made ground in Indonesia into the suction device including exploitation by foreign capital against the people of Indonesia. This ambiguity is a form of legal uncertainty and therefore contrary to the rule of law as referred to Article 1 Paragraph (3) The RI State Constitution of 1945. Implementation of Legislation on Investment Number 25 of 2007 concerning Foreign Investment, which has a better part from the past such as:

- Their equal treatment to foreign investors and domestic,

- Their responsibility for capital investment,

- Sanctions for investors,

- Their rights to land,

- The prohibition of nominee shareholders,

- Investors holding their affairs,

- Coordination of policy implementation investors.

The UUPMA advantage for investors is that there is equal treatment of investors, guarantees no nationalization, and immigration facilities for foreign investors. In UUPMA Article 3 Paragraph (1) states that the investments held by the principle of legal certainty, transparency, accountability, equal treatment and did not distinguish the origin of the country, unity, efficiency, justice, sustainability and environmental friendliness, independence, balance of progress and national economic unity. ${ }^{7}$ Beside that, Agreement on Trade Related Investment Measures (TRIMs) has made the principle of non-discrimination, which is not distinguishing between foreign investor and local investor, investing itself is a state borderless. ${ }^{8}$

Another advantage for the investor is given immigration facility for foreign investors as stipulated in Article 23 UUPMA. This can be seen in Article 23 Paragraph (3) which states, immigration facility for foreign investors, the limited residential permit for foreign investors with a validity period of 2 (two) years is given for a maximum period of 24 (twenty-four) months since the limited stay permit granted. Granting reentry permit for several trips to holders of permanent residency granted for a maximum period of 24 (twenty four) months commencing granted permanent residency.

\footnotetext{
${ }^{6}$ Act No. 25 of 2007 on FDI

${ }^{7}$ Article 3 Paragraph (1) of Law No. 25 of 2007 on Investment.

${ }^{8}$ Salim HS and Budi Sutrisno, 2007, Hukum Investasi di Indonesia, Jakarta: Raja Grafindo Persada, p. 15-16.
} 
Legal certainty is one of the essential principles of the legal state. The function of the rule of law, among others, to provide a benchmark for behavior that is orderly, peaceful, and fair. ${ }^{9}$ Written laws ensure legal certainty, though not the only source of law. Legal certainty needs to be aligned with other legal purpose, namely justice and expediency. The application of written laws also need to be considered laws that live and thrive in the community (living law). In Indonesia the principle of legal certainty does not serve as the sole principle in the Indonesian legal system. ${ }^{10}$

Concerns for potential foreign investors is a legal guarantee of capital recipient countries, especially with regard to non-commercial risks. One form of non-commercial risks is expropriation or nationalization of foreign companies. ${ }^{11}$ To further increase the confidence of foreign investors in investing in Indonesia, the Government of Indonesia to make bilateral agreements with various countries of origin of investors.

\subsection{Protection of Investor Interests On Investing in the Era of Regional Autonomy Under Regulation}

Advantages of investing in Indonesia, among others, as it has abundant natural resources such as natural gas, oil, mining, and so forth. Whatever the product produced by the investor will be easily sold on the market. Then Indonesia has also had a good political stability. This is an important factor for investors, because for their good political stability, investors only need to focus on investment activities.

This activity is also supported on the operational side, which is where the need for cooperation with the local government. This cooperation in order to facilitate investors to be able to obtain the location or place to invest, as the place obtained by looking at permissions from local authorities. So it is necessary to permit the proper investment, which is expected to encourage private investment to develop business in each region in Indonesia, it is necessary to factor the licensing system is spearheading the national investment promotion.

If the permit system in an area does not make it easy for investors who wish to invest in the region, can in terms of investment promotion can be inhibited and can not attract investors to invest in the area. That's needed for the legal safeguards for investors in order to improve the investment climate in the era of regional autonomy. The government needs to be careful in issuing integrated service model policy, be it a one-stop service system (one roof services) as well as one-stop service system (onestop services),

The potential of the latter is the Indonesian government's efforts to improve the investment climate. One of them with increasingly facilitate licensing in investment has been much easier than before. Now there is a system called Online Single Submission, known as OSS which makes the investment license easier, faster, and practical.

Progress of technology development and interest investor in Indonesia has made easy for foreign investors, so it needs a pull factor (pull factors) that exist in the recipient country capital. It means with related policies to provide incentives in the field of taxation, with adequate infrastructure, available workforce that is skilled and disciplined, which makes the interest of investors in Indonesia one of them.

So as to be able to invest the investor will also consider how legal certainty and legal protection for him. Investor protection is the duty of the central government and local

\footnotetext{
9 ibid, P. 187.

${ }^{10}$ Mahfud MD, 2007, Kepastian Hukum Tabrak Keadilan, in Fajar Laksono, Ed., Hukum Tak Kunjung Tegak: Tebaran Gagasan Otentik Mahfud, Bandung: Citra Aditya Bakti, p. 89.

11 Ibid
} 
Volume 7 Issue 2, June 2020

Nationally Accredited Journal,

Decree No. B/4130/E5/E5.2.1/2019

governments to ensure certainty and security sought for the implementation of the investment. Legal certainty is given by the provisions of the legislation earlier this sometimes gives uncertainty for foreign investors. Foreign investor protection in the provisions of laws and regulations No. 25 of 2007 concerning Foreign Investment, there are several provisions related to the protection of foreign investors, as set out terms regarding the provision of equal treatment to all investors in Article 6 paragraph (1): "The government gives equal treatment to all foreign investors who come from any country that conduct investment activities in Indonesia in accordance with the provisions of the legislation".

The government must be able to convince the investors with legal certainty and ensure that the law in Indonesia justly, to provide protection in the regulations of the Act PMA which is about nationalization and compensation provisions in Article 7 paragraph (13).

In the case of other safeguards contained in chapters 8 and 9, the rules concerning the transfer of assets by way of transfer and repatriation of foreign currency. Some of this article clearly has guaranteed investors to easily invest according to the law and simplify the business to be run foreign investors without discrimination.

Government can rely on foreign investors as one of the leading foreign exchange. If the investment is partially to invest in the country has a positive effect and significantly increase economic growth of Indonesia. ${ }^{12}$ Because these figures and the economic value of domestic investment for the region 33 provinces in Indonesia is very good, because of the encouragement of investment climate, infrastructure with abundant natural resources and a good domestic market. ${ }^{13}$

After Indonesia joined the organization's International in International conventions to ratify International Center for Settlement of Investment Disputes (ICSID) to be adjusted to Legislation No. 5 of 1968 on the Settlement of Disputes Between States and Nationals Regarding Foreign Investment. ICSID also organize the International Convention member states to agree to resolve disputes through ICSID, governed by Article 25 paragraph (1):

"The jurisdiction of the Center shall extend to any legal dispute Arising directly out of an investment, between a Contracting State (or any constituents subdivision or agency of a Contracting State designated to the Center by the State) and a national of another Contracting State, roommates the parties to the dispute consent in writing to submit to the Center. When the parties have given Reviews their consent, no party may withdraw its consent unilaterally. "

The existence of this Convention with the aim to encourage economic investment for other developing countries. By becoming a member of the International Convention is to convince the international community that Indonesia is able to compete in the economy and developing the capital market.

\section{Closing}

\subsection{Conclusion}

\footnotetext{
${ }^{12}$ Lainatul Reza Rizky, Grisvia Agustin, Imam Mukhlis, 2016, Pengaruh Penanaman Modal Asing, Penanaman Modal Dalam Negeri dan Belanja Modal Terhadap Pertumbuhan Ekonomi Provinsi di Indonesia, Journal of Economics and Development Studies, Vol. 8, No. 1 (March), p. 14.

13 ibid
} 
Function Notary / PPAT in the filing process of acquiring land rights based on foreign investment regulations number 25 in 2007. The function of Notaries easier for the public to take legal actions both Indonesian citizens or citizens of foreign countries who participate in investing in Indonesia. The Indonesian government also needs to prepare for national law and the law of international relations International to establish it. Government to maintain legal certainty for foreign investors without discrimination by being able to compete with domestic investors. Protection of the interests of investors in investing in regional autonomy based on legislation.

\subsection{Suggestion}

Notary functions also continue to be supported in order to facilitate the rights of use and rights of exploitation for investors to economy climate road and business activities in Indonesia. Legislation set out in the Act FDI for Foreign Investors, giving foreign investors the opportunity to expand its business, regarding the Indonesian government firmly guarantee any things that ensure legal certainty for investors. Efforts are built to attract investment in Indonesia is not followed by ensuring legal certainty for investment. This problem resulted in the investors are reluctant to invest in Indonesia. So it needs a foreign investor protection for investors, seen from basically, government obligations and / or regional governments is to ensure certainty and security sought for the implementation of the investment. To ensure the certainty and security that need to be regulated authority of government, provincial, and district / city in investment activity.

\section{References}

[1] MD, Mahfud, 2007, Kepastian Hukum Tabrak Keadilan, in Fajar Laksono, Ed., Hukum Tak Kunjung Tegak: Tebaran Gagasan Otentik Mahfud, Bandung: Citra Aditya Bakti

[2] Mertokusumo, Sudikno 2010, Perundang-undangan Agraria Indonesia, Yogyakarta: Liberty

[3] Salim HS and Budi Sutrisno, 2007, Hukum Investasi di Indonesia, Jakarta: Raja Grafindo Persada

[4] Santoso, Urip, 2014, Pendaftaran dan Peralihan Hak Atas Tanah, Jakarta: Kencana Prenada Media-Matter to VI

[5] Lainatul Reza Rizky, Grisvia Agustin, Imam Mukhlis, 2016, Pengaruh Penanaman Modal Asing, Penanaman Modal Dalam Negeri dan Belanja Modal Terhadap Pertumbuhan Ekonomi Provinsi di Indonesia, Journal of Economics and Development Studies, Vol. 8, No. 1 (March)

[6] Act No. 25 of 2007 on Investment 